\title{
Inhibition of estrogen receptor positive and negative breast cancer cell lines with a growth hormone-releasing hormone antagonist
}

\author{
STEPHAN SEITZ ${ }^{1,2}$, FLORIAN HOHLA ${ }^{1,6}$, ANDREW V. SCHALLY ${ }^{1,2,4}$, ANGELIKA MODER ${ }^{7}$, \\ JOERG B. ENGEL ${ }^{5}$, FELICITAS HORN ${ }^{2}$, JOSEF VARGA ${ }^{1}$, MARTA ZARANDI $^{1}$, \\ OLAF ORTMANN $^{2}$, FRANK KÖSTER ${ }^{3}$ and STEFAN BUCHHOLZ $Z^{1,2}$ \\ ${ }^{1}$ Veterans Affairs Medical Center Miami FL and South Florida VA Foundation for Research and Education, \\ Miami, and Department of Pathology and Division of Hematology and Oncology, Department of Medicine, \\ the Miller School of Medicine, University of Miami, FL 33101, USA; ${ }^{2}$ Klinik für Frauenheilkunde und \\ Geburtshilfe der Universität Regensburg; ${ }^{3}$ Klinik für Frauenheilkunde und Geburtshilfe der Universität \\ zu Lübeck, Germany; ${ }^{4}$ Endocrine, Polypeptide and Cancer Institute, VA Medical Center, 1201 North East 16th St., \\ Miami, FL 33125-1693, USA; ${ }^{5}$ Universität Frauenklinik Würzburg, Würzburg, Germany; ${ }^{6}$ Department of \\ Internal Medicine, General Hospital Oberndorf, Teaching Hospital of the Paracelsus Private Medical \\ University of Salzburg, Paracelsusstrasse 37, 5110 Oberndorf; ${ }^{7}$ Department of Physiology and \\ Pathophysiology Paracelsus Private Medical University of Salzburg, Salzburg, Austria
}

Received June 2, 2008; Accepted July 14, 2008

DOI: 10.3892/or_00000143

\begin{abstract}
GHRH antagonists have been shown to inhibit growth of various human cancer cell lines xenografted into nude mice including estrogen receptor negative human breast cancers. Previous observations also suggest that GHRH locally produced in diverse neoplasms including breast cancer might directly affect proliferation of tumor cells. In the present study we demonstrate that a novel highly potent GHRH antagonist JMR-132 strongly inhibits the proliferation of both estrogen receptor negative SKBR 3 and estrogen receptor positive ZR 75 human breast cancer cell lines in vitro. The proliferation in vitro of ZR 75 and SKBR 3 was increased after direct stimulation with GHRH(1-29) $\mathrm{NH}_{2}$. The GHRH antagonist JMR-132 had a significant antiproliferative activity in the absence of GHRH and nullified the proliferative effect of GHRH in these cell lines. SKBR 3 and ZR 75 expressed the GHRH ligand as well as the pituitary type of GHRHreceptor, which likely appears to mediate the antiproliferative mechanisms in these cell lines. These in vitro results suggest that JMR-132 is a potent inhibitor of breast cancer growth, independent of the estrogen receptor status. Further
\end{abstract}

Correspondence to: Dr Andrew V. Schally, Endocrine, Polypeptide and Cancer Institute, VA Medical Center, 1201 North East 16th St., Miami, FL 33125-1693, USA

E-mail: andrew.schally@va.gov

Abbreviations: GHRH, growth hormone-releasing hormone; GHRH-R, full length GHRH receptor; ER, estrogen receptor; PR, progesterone receptor; GPCR, G protein coupled receptor

Key words: breast cancer, GHRH, estrogen receptor investigations on the combination treatment with endocrine agents affecting the estrogen pathway and GRHR antagonists are needed in order to improve the treatment of breast cancer.

\section{Introduction}

Breast cancer is a leading cause of cancer related death among women in the western world. About 40,000 women in the United States die of breast cancer every year (1). The expression of the sex-hormone receptors is of a prognostic and predictive value. Most of breast cancers are positive for estrogen and progesterone hormone receptors (2) and respond to the standard endocrine treatment with Tamoxifen or an aromatase inhibitor. Over the last decade various investigators demonstrated the impact of neuropeptides and growth factors, synthesized locally by the tumor or derived from systemic circulation, in promoting the proliferation of breast cancer and other malignancies (3). The presence of growth hormonereleasing hormone (GHRH) and its receptors in extrahypothalamic tissue and tumors suggested that GHRH might exert proliferative action in these tissues. Much evidence has accumulated that GHRH and its receptors are involved in carcinogenesis (3-6). The mRNA for GHRH has been demonstrated in surgical specimens of human prostate, breast, ovarian, endometrial, pancreatic cancers and other cancers (7-10). In addition, various cancer cell lines including cell lines derived from breast cancer express mRNA for the GHRH peptide (11). Previous studies also showed that GHRH and its receptors are expressed in benign as well as malignant breast tissue and human breast cancer cell lines (10). These findings provide a rationale for the development of new treatment strategies for estrogen-dependent as well as independent breast cancer, for which current therapeutic options are not satisfactory. 
In the course of investigations of new anticancer drugs which act by disrupting endocrine and autocrine/paracrine stimulatory loops of tumor proliferation, GHRH antagonists have been shown to be potential inhibitors of cancer growth in a variety of human malignancies, such as colon and prostate cancer as well as breast cancer $(3,12)$. GHRH antagonists developed in our laboratory act in part indirectly by inhibiting the release of GH from the pituitary gland and thus suppress the production of insulin-like growth factor I (IGF I) in the liver and other organs (4). IGF-I is a well known mitogen for malignant tissues including breast cancer (13). Recent evidence shows that also GH plays a oncogenic role in breast cancer $(14,15)$. Thus, suppression of the GH/IGF-1 axis by GHRH antagonists would contribute to tumor growth inhibition. The direct mechanism of action of GHRH antagonists on breast cancer cell lines was demonstrated in vitro, where the systemic GHRH/GH/IGF-I loop is clearly lacking $(16,17)$. The direct antiproliferative effect of GHRH antagonists appears to be mediated through GHRH receptors and their splice variants $(18,19)$. The detection of biologically and immunologically active GHRH in tissue and cell lines supports the view that locally produced GHRH plays a major role in the proliferation of tumors (9). In previous studies, experimental human breast cancer cell lines such as T47D showed a proliferation after a stimulation with exogenous GHRH in vitro (11). This growth stimulation was inhibited by the GHRH antagonist JV-1-38. T47D cells express mRNA for GHRH (11), suggesting an autocrine loop. The antiproliferative effect of GHRH antagonists could be mediated by the splice variants of the GHRH receptor (11) but the expression of the pituitary type of GHRH receptor is also present in breast cancer cell lines. The pituitary type GHRH receptor influences on two major signaling pathways which involve the second messenger cAMP and $\mathrm{Ca}^{2+}(20)$. Apart from these signaling mechanism GHRH can also activate, inositol triphosphate production and protein kinase $\mathrm{C}$ (PKC) in these cell lines (21). Siriwardana et al showed a proliferative effect of exogenous GHRH on MDA-MB-231 breast cancer cell line through a Ras, Raf and mitogen activated protein kinase (MAPK) pathway (22).

The aim of the present study was to investigate the expression of GHRH and its receptors in established estrogen receptor ER-positive ZR 75 and ER-negative SKBR 3 cell lines and to evaluate the stimulatory effect of GHRH and the antiproliferative action of the new GHRH antagonist JMR-132.

\section{Materials and methods}

Peptides and chemicals. The GHRH antagonist JMR-132 $\left[\mathrm{PhAcTyr}^{1}, \mathrm{D}-\mathrm{Arg}^{2}, \mathrm{P}_{\mathrm{H}} \mathrm{e}(4-\mathrm{CL})^{6}, \mathrm{Ala}^{8}, \operatorname{Har}^{9}, \operatorname{Tyr}(\mathrm{Me})^{10}, \mathrm{His}^{11}\right.$, $\left.\mathrm{Abu}^{15}, \mathrm{His}^{20}, \mathrm{Nle}^{27}, \mathrm{D}-\mathrm{Arg}^{28}, \mathrm{HLCr}^{29}\right]$ GHRH(1-29) $\mathrm{NH}_{2}$, where Abu is $\alpha$-aminobutyric acid, Har is homoarginine, Nle is norleucine, $\mathrm{PhAc}$ is phenylacetyl and $\operatorname{Tyr}(\mathrm{Me})$ is $\mathrm{O}$ methyltyrosine, was synthesized in our laboratory by solid phase methods $(5,23)$.

Cell culture. Estrogen-dependent human breast cancer cell line ZR 75 originating from a surgical explant, was kindly donated by Professor A. Buschauer (Clinical Pharmacology,
Regensburg). Hormone-independent SKBR 3 human breast cancer line was obtained from American Type Culture Collection (Manassas, VA, USA). Cells were cultured at $37^{\circ} \mathrm{C}$ in a humidified $95 \%$ air and $5 \% \mathrm{CO}_{2}$ atmosphere. For routine maintenance, cells were propagated in $75-\mathrm{cm}^{2}$ flasks containing complete RPMI-medium consisting in RPMI-1640 with Phenol red supplemented with 5\% heat-inactivated fetal bovine serum (FBS) and L-glutamine, penicillin and streptomycin at standard concentrations (all from Gibco BRL, Life Technologies, Merelbeke, Belgium). Cells were harvested by trypsinization ( $0.1 \%$ trypsin $0.02 \%$ EDTA) and subcultured twice weekly.

\section{$R T-P C R$}

$R N A$ isolation and reverse transcription. Total RNA extraction of tumor and pituitary cells (positive control) was performed by a guanidinium-isothiocyanate-phenol-chloroform based procedure as described (24). After extraction and precipitation, total RNA was dissolved in RNase free water (Fermentas, Ontario, Canada) and stored at $-80^{\circ} \mathrm{C}$. Between 2 and $5 \mu \mathrm{g}$ total RNA was reverse transcribed using RevertAid H Minus M-MuLV Reverse Transcriptase cDNA kit (Fermentas) with random hexamer primers according to the manufacturer's instruction.

Reverse-transcriptase (RT-) PCR. RT-PCR for human GHRH ligand, full length and SV1 receptor was performed as described previously with slight modifications (19). PCR solution used for amplification of GHRH-R and SV1 consisted of 1X iTaq buffer (Bio-Rad, Hercules, CA), $4 \mathrm{mM} \mathrm{MgCl}_{2}$, $0.25 \mathrm{mM}$ dNTPs, $0.2 \mu \mathrm{M}$ primers and $0.25 \mathrm{U}$ iTaq polymerase (Bio-Rad). Normal human pituitary was used as positive control, and GAPDH (5'-GTGAAGGTCGGAGTCAACG, 3'-TGAGGTCAATGAAGGGGTC) was used as a housekeeping gene. Negative samples were run for each RT-PCR consisting of no RNA in the reverse transcriptase reaction and no cDNA in the PCR. PCR fragments were separated on a 2\% Agarose-TBE Gel. Tissues which did not show the corresponding bands for GHRH-R or SV 1 were considered negative for these receptors.

Cell viability assay. For in vitro experiments 2500 cells/well of SKBR 3 or ZR 75 cells, were seeded in 96-well plates. Media containing 10\% FBS was replaced with media supplemented with $1 \mathrm{X}$ serum reduced media (SR2) instead of FBS after $24 \mathrm{~h}$. Cells were treated with $100 \mathrm{nM} \mathrm{GHRH}(1-29) \mathrm{NH}_{2}$, $10 \mu \mathrm{M}$ GHRH antagonist JMR-132 alone or in combination with GHRH(1-29) $\mathrm{NH}_{2}$, respectively. Experiments were performed in triplicates and repeated three times. After $72 \mathrm{~h}$ relative numbers of viable cells were measured in comparison with the untreated control and the solvent control using fluorimetrical, resazurin-based Cell Titer Blue Assay (Promega) according to the manufacturer's instructions at $560_{\mathrm{Em}} / 590_{\mathrm{Em}} \mathrm{nm}$ in a Victor3 multilabel counter (PerkinElmer, Waltham, MD, USA). Cell growth was expressed as percentage of the untreated medium control. Statistical analysis of the data was performed by one way ANOVA using Sigma Stat, with statistical significance accepted at $(\mathrm{p}<0.001)$ and Student's t-test, with statistical significance accepted at $(\mathrm{p}<0.05)$ 


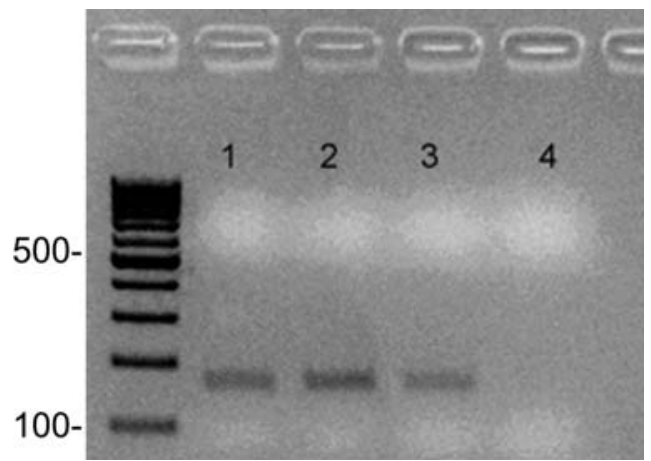

Figure 1. Expression of mRNA for GHRH in SKBR 3 (lane 1) and ZR 75 (lane 2). Lane 3 shows mRNA for GHRH in the human pituitary. Lane 4, negative control.

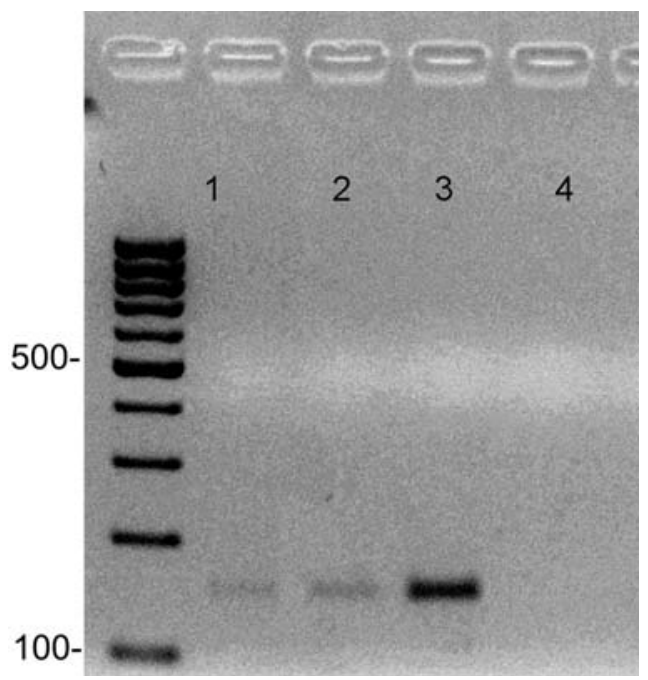

Figure 2. Expression of mRNA of the pituitary type receptor of GHRH in SKBR 3 (lane 1) and ZR 75 (lane 2). Lane 3 shows mRNA for the GHRH receptor of the pituitary gland. Lane 4 is the primer product control.

\section{Results}

Expression of mRNA for GHRH in human breast cancer cells. Extracted cDNA of both cell lines was subjected to RT-PCR and amplicons of interest were subsequently visualized by gel electrophoresis (Figs. 1 and 2). Normal human pituitary served as positive control. mRNA for GHRH was detected by RT-PCR in both cell lines (Fig. 1). RT-PCR with primers specific for human GHRH yielded a product of the expected size of $150 \mathrm{bp}$ in ZR 75 and SKBR 3 breast cancer cells. This band corresponds to mRNA for GHRH, identified in the positive control.

mRNA for the pituitary type GHRH-R was also expressed in ZR 75 and SKBR 3 cells (Fig. 2), as seen by the presence of amplification products of the expected size of $145 \mathrm{bp}$ in both cell lines as well as in the pituitary positive control. mRNA for SV 1 GHRH receptor could not be detected (Fig. 3).

Effect of GHRH and GHRH antagonist JMR-132 on the proliferation of ZR 75 and SKBR 3 cells. ZR 75 cells cultured in vitro were exposed to various concentration of GHRH(1-29) $\mathrm{NH}_{2}$ and GHRH antagonist JMR-132 to

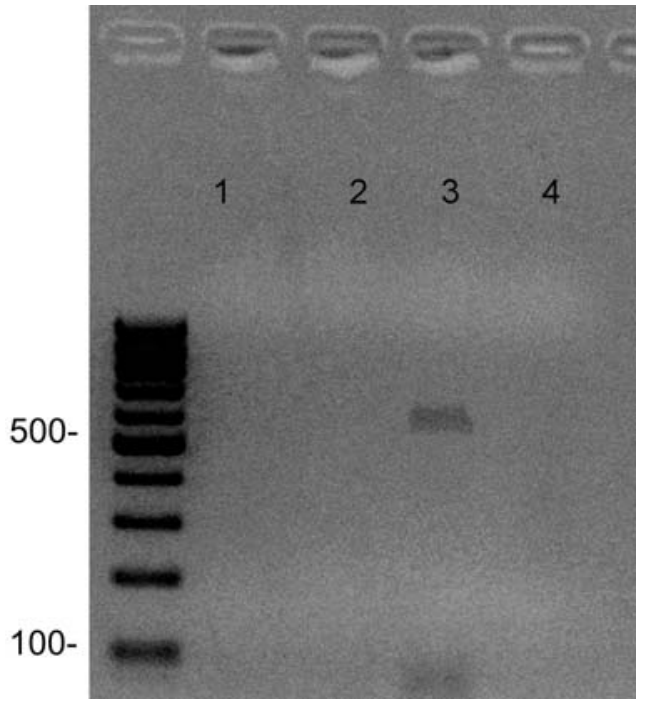

Figure 3. Lack of expression of mRNA for SV1 in SKBR 3 (lane 1) and ZR75 human breast cancer cell lines (lane 2). Lane 3 represents mRNA GHRH in the pituitary gland. Lane 4 , negative control.

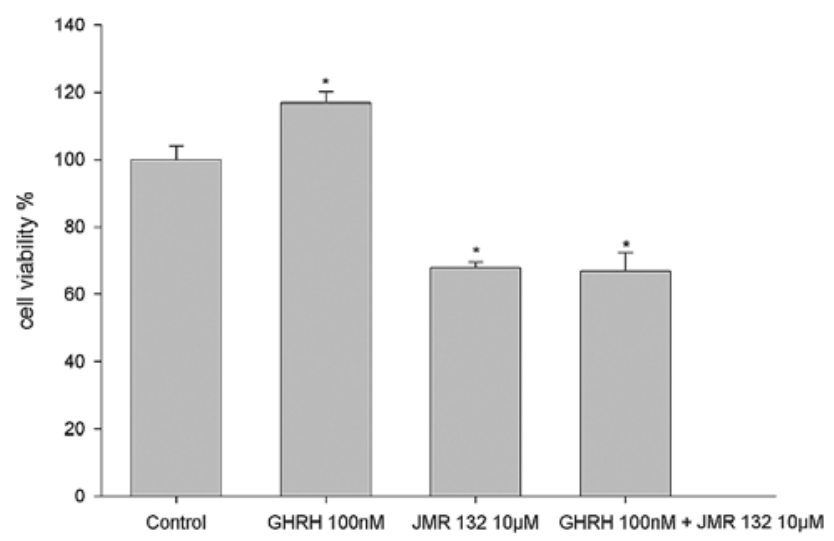

Figure 4. Inhibitory effects of GHRH antagonist JMR-132 in ZR 75 breast cancer cell line. Proliferation assay on ZR 75 cell line. GHRH stimulated the proliferation of ZR 75 cells at a concentration of $100 \mathrm{nM}$. GHRH antagonist JMR-132 at $10 \mu \mathrm{M}$ inhibited the proliferation and abolished the effect of exogenous GHRH.

investigate its inhibitory potential. The rate of proliferation was measured with the crystal blue violet assay. GHRH concentration of $100 \mathrm{nM}$ produced a significant increase in cell number $(16 \%)(\mathrm{p}<0.05)$ of ZR 75 cells. The GHRH antagonist JMR-132 at a concentration of $10 \mu \mathrm{M}$ was able to significantly $(\mathrm{p}<0.001)$ inhibit the proliferation of ZR 75 cells by $48 \%$ after $72 \mathrm{~h}$ of incubation. JMR-132 also nullified the

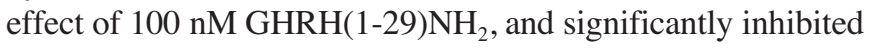
the proliferation of ZR 75 cells stimulated with GHRH (Fig. 4).

The proliferation of SKBR 3 cells could not be stimulated by exogenous GHRH, at various dosages (data not shown). Nevertheless, the GHRH antagonist JMR-132 at a dosage of $10 \mu \mathrm{M}$ produced a significant reduction of $49 \%$ in the growth in the SKBR 3 cell line $(\mathrm{p}<0.001)$ (Fig. 5). Antagonist JMR-132 also showed an antiproliferative effect at lower concentration of $0.1 \mu \mathrm{M}(11 \%)$ and $1 \mu \mathrm{M}(14 \%)$, respectively (Fig. 5). 


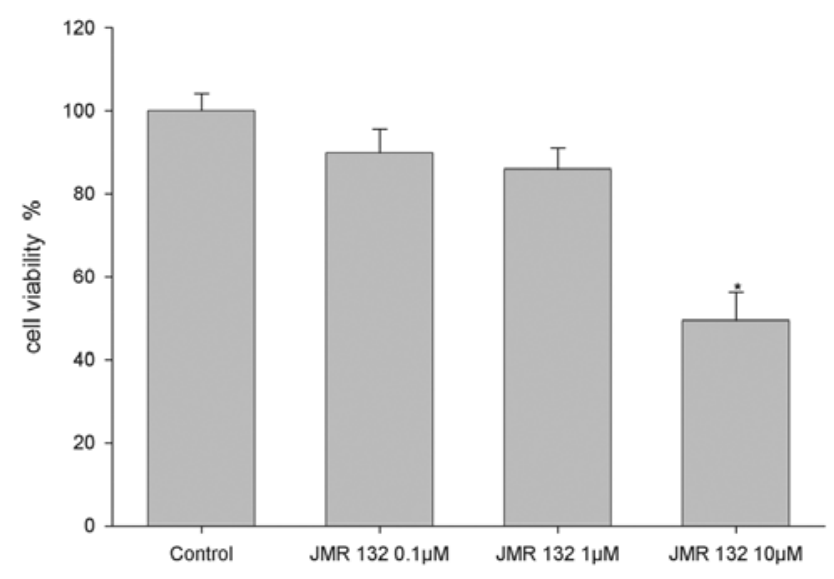

Figure 5. The inhibitory effects of GHRH antagonist JMR-132 in SKBR 3 human breast cancer cells. The response of SKBR 3 human breast cancer cells to the GHRH antagonist JMR-132 at different concentrations. A significant inhibition of proliferation was found at $10 \mu \mathrm{M}$.

\section{Discussion}

Increasing evidence shows that various human cancers including breast cancer produce GHRH (25-27). However, the pathophysiological significance of these findings and the mechanisms are at present only partially perceived. Therefore, in the present study we investigated GHRH and its receptors in two human breast cancer cell lines which are expressed independently of the estrogen receptor status. RT-PCR analyses showed the presence of mRNA for GHRH in SKBR3 and ZR 75 cells. The full length pituitary type receptor for GHRH was demonstrated by RT-PCR in the ZR 75 as well as SKBR 3 human breast cancer cell line. After exposing ZR 75 breast cancer cells to GHRH, Csernus et al demonstrated a transient increase in cAMP release from the cells, which is considered as a potent second messenger (28). Recently, Siriwardana et al demonstrated the endogenous production of GHRH in an estrogen receptor negative breast cancer cell line. Furthermore, their results show a GHRH dose-dependent increase cell proliferation of the MDA-MB- 231 breast cancer cell line (22). There is relatively little knowledge regarding the mechanisms of action of GHRH in cancer cells, but the phosphorylation of MAPK after GHRH treatment has been demonstrated previously $(22,29)$. Multiple reports demonstrated that antagonists of GHRH have an antiproliferative effect on a variety of human tumor types in vivo and in vitro (30-32). These rsults suggest that GHRH is a mitogenic growth factor. Our study demonstrates by RT-PCR that GHRH is present in SKBR 3 and ZR 75 cells and that cell proliferation is inhibited by the GHRH antagonist JMR-132. Thus, in breast cancer, GHRH is expressed by tumor cells and may serve as an autocrine growth factor. Proliferation studies with various breast cancer cell lines including estrogen receptor positive cells such as $\mathrm{T} 47 \mathrm{D}$ indicate that stimulation with exogeneous GHRH(1-29) $\mathrm{NH}_{2}$ increases the rate of cell proliferation, even if autocrine GHRH was already present in the cells. It has been shown that human breast cancers ZR 75, MX-1 and MCF-7 MII grown in nude mice, contain nanomolar concentrations of GHRH or about $3 \mathrm{ng}$ peptide/g tissue (33).
However, under the experimental conditions of in vitro proliferation, higher concentrations of GHRH and antagonists, in the range of $\mu \mathrm{M}$ are necessary in order to significantly alter the rate of cell growth (14,16-35). Our results in the ZR 75 cell line show that $100 \mathrm{nM}$ GHRH(1-29) $\mathrm{NH}_{2}$ was sufficient to stimulate the proliferation of the cells. However, exogenous GHRH(1-29) $\mathrm{NH}_{2}$ did not induce a proliferation on SKBR 3 cells which might be due to the fact that this line produces sufficient endogenous GHRH and thus exogenous GHRH causes no further stimulation. Nevertheless, JMR-132 led to a significant inhibition of proliferation of SKBR 3 breast cancer cells. The GHRH antagonist JMR-132 was also able to nullify the effects of GHRH on the proliferation in ZR 75 cell line. However JMR-132 produced essentially the same inhibition of cell growth in the presence or absence of GHRH. This is explained by the fact that potent GHRH antagonists including JMR-132 have an increased binding affinity to the tumoral and pituitary GHRH receptors that is typically 20 to 100 -fold higher than that of the native GHRH $(4,5)$.

The GHRH receptor is a member of the superfamily of $\mathrm{G}$ protein coupled receptors (GPCRs) with seven helical transmembranes. In MCF-7 breast cancer cells transfected with the cloned human GHRH receptor, GHRH stimulates the proliferation (36). The ability of the GHRH receptor to react to mitogenic stimuli in somatotroph cells is underlined by the finding that deregulation of the signaling in various components of the cell has been implicated in several clinical disordes. Recently, it was shown that pituitary GHRH-R transfected into breast cancer cells can mediate mitogenic effects by mechanisms that involve the signaling pathways of Ras, Raf and MAPK (22). In contrast to the full length receptor of GHRH, the splice variant 1 (SV1) represents a product of alternative splicing of GHRH-R and differs from it in a small part of the extracellular portion of the receptor protein. SV1 is widely expressed in various human cancers $(3,5,23)$ including breast cancers $(7,11,34)$ and responds to GHRH with proliferation as shown in NIH-3T3 fibroblasts and MCF-7 human breast cancer cells transfected with SV1 $(36,37)$. Previous studies on breast, prostatatic, pancreatic and other cancers showed that many cancers lines that are stimulated by GHRH and inhibited by GHRH antagonists express SV1 receptors, but not the full length GHRH-R. This indicates that SV1 could be the main tumoral receptor responsible for the mediating effects of GHRH and its antagonists in these cancers $(3,5,16-18,27)$. Kahan et al (16) found that GHRH antagonists strongly inhibited the growth of MDA-MB-468 human estrogen receptor negative breast cancer in vivo and in vitro. Nevertheless, the nature of GHRH receptor on tumor cells sensitive to GHRH effects remained elusive, since the expression of pituitary-type, full length receptors for GHRH could not be demonstrated in MDA-MB-468 cell line. Subsequently, Rekasi et al (18) found that various human cancer lines, including MDA-MB-468 breast cancers expressed truncated splice variants receptors for GHRH of which SV1 most closely resemble the full length receptor. Nevertheless the full length receptor itself was not expressed by these cancer cell lines. Further studies demonstrated the expression of SV1 receptors in human breast cancer lines $(11,34)$ and surgical specimens of breast cancer $(7)$, but 
previous work indicated absence of pituitary type full-length receptors in various cancers. The possible expression of fulllength GHRH-R was not investigated $(7,11,34)$. However subsequently, our laboratory re-examined the expression of the full-length GHRH-R in human tumors and extra pituitary tissues. It was then revealed that certain human cancer lines including lymphomas, glioblastomas and lung cancers express the pituitary type of the full-length GHRH-R as well as the truncated SV1 receptor (19). In the present study we determined by RT-PCR that mRNA for the full length receptor for GHRH is present in both tested cell lines ZR 75 and SKBR 3. The SV1 receptor was not detected in either cell line. To our knowledge, this is the first report showing that certain cancers express only the pituitary GHRH-R without the co-expression of SV1, and that GHRH antagonists inhibit the proliferation of such cancers. In other studies, proliferative effects of GHRH and antiproliferative effects of GHRH antagonists were demonstrated in MCF-7 breast cancer cells, that do not express GHRH-R, after transfection with the full length GHRH-R $(22,36)$. Conversely knocking down the of GHRH gene expression using siRNA suppressed the proliferation of T 47D and MDA-MB-468 breast cancer lines (38).

Our study shows that the GHRH antagonist is a potent inhibitor of proliferation of estrogen receptor positive and negative breast cancers that express the pituitary type of GHRH-R. The mechanism of activation of signaling pathways by different growth factors such as estrogens, GHRH, and other mitogenic agents might permit interference at different levels of this pathway by a combination of various therapeutic agents with low toxicity such as GHRH antagonists, SERMS like tamoxifen or aromatase inhibitors.

\section{Acknowledgements}

This study was supported by a grant from the Medical Research Service of the Veterans Affairs Department and a grant from ZENTARIS GmbH (Frankfurt am Main, Germany) to SFVAE (all to AVS).

\section{References}

1. Jemal A, Murray T, Ward E, Samuels A, Tiwari JC, Ghafoor A, Feuer EJ and Thun MJ: Cancer statistics, 2005. CA Cancer J Clin 55: 10-30, 2005.

2. Anderson WF, Chaterjee N, Ershler WB and Brawley OW: Estrogen receptor breast cancer phenotypes in survelliance, epidemology, and end results database. Breast Cancer Res Treat 76: 27-36, 2002.

3. Schally AV, Comaru-Schally AM, Nagy A, Kovacs M, Szepeshazi K, Plonowski A, Varga JL and Halmos G: Hypothalamic hormones and cancer. Front Neuroendocrinol 22: 248-291, 2001.

4. Schally AV and Varga JL: Antagonistic analogs of growth hormone-releasing hormone: new potential antitumor agents. Trends Endocrinol Metab 10: 383-391, 1999.

5. Varga J and Schally AV: Handbook of Peptides. Kastin A (ed). Elsvier-Academic, New York, pp483-489, 2006.

6. Schally A, Varga JL and Engel JB: Antagonists of growthhormone-releasing hormone-releasing hormone: an emerging new therapy for cancer. Nat Clin Pract Endocrinol Metab 4: 33-43, 2008.

7. Chatzistamou I, Schally AV, Kiaris H, Politi E, Varga J, Kanellis G, Kalofoutis A, Pafiti A and Koutselini H: Immunohistochemical detection of GHRH and its receptor splice variant 1 in primary human breast cancers. Eur J Endocrinol 151: 391-396, 2004.
8. Halmos G, Schally AV, Czompoly T, Krupa M, Varga JL and Rekasi Z: Expression of growth hormone-releasing hormone and its receptor splice variants in human prostate cancer. J Clin Endocrinol Metab 87: 4707-4714, 2002.

9. Kahan Z, Arencibia JM, Csernus VJ, Groot K, Kineman RD, Robinson WR and Schally AV: Expression of growth hormonereleasing hormone $(\mathrm{GHRH})$ messenger ribonucleic acid and the presence of biologically active GHRH in human breast, endometrial, and ovarian cancers. J Clin Endocrinol Metab 84: $582-589,1999$.

10. Khorrmam O, Garthwaite M, Grosen E and Golos T: Human uterine and ovarian expression of growth hormone releasing hormone messanger mRNA in beign and malignant gynecological conditions. Fertil Steril 75: 174-179, 2001.

11. Garcia-Fernandez MO, Schally AV, Varga JL, Groot K and Busto R: The expression of growth hormone-releasing hormone (GHRH) and its receptor splice variants in human breast cancer lines; the evaluation of signaling mechanisms in the stimulation of cell proliferation. Breast Cancer Res Treat 77: 15-26, 2003.

12. Kahan Z, Sun B, Schally AV, Arencibia JM, Cai RZ, Groot K and Halmos G: Inhibition of growth of MDA-MB-468 estrogenindependent human breast carcinoma by bombesin/gastrinreleasing peptide antagonists RC-3095 and RC-3940-II. Cancer 88: 1384-1392, 2000.

13. Pollak M: Endocrine effects of IGF-I on normal and transformed breast cancer epithelial cells: potential relevance to strategies for breast cancer treatment and prevention. Breast Cancer Res Treat 47: 209-217, 1998.

14. Szepeshazi K, Schally AV, Armatis P, Groot K, Hebert F, Feil A, Varga JL and Halmos G: Antagonists of GHRH decrease production of GH and IGF-I in MXT mouse mammary cancers and inhibit tumor growth. Endocrinology 142: 4371-4378, 2001.

15. Waters M and Conway-Campbell BL: The oncogenic potential of autocrine human growth hormone in breast cancer. Proc Natl Acad Sci USA 101: 14992-14993, 2004.

16. Kahan Z, Varga JL, Schally AV, Rekasi Z, Armatis P, Chatzistamou L, Czompoly T and Halmos G: Antagonists of growth hormone-releasing hormone arrest the growth of MDAMB-468 estrogen-independent human breast cancers in nude mice. Breast Cancer Res Treat 60: 71-79, 2000.

17. Rekasi Z, Varga JL, Schally AV, Halmos G, Armatis P, Groot K and Czompoly T: Antagonists of growth hormone-releasing hormone and vasoactive intestinal peptide inhibit tumor proliferation by different mechanisms: evidence from in vitro studies on human prostatic and pancreatic cancers. Endocrinology 141: 2120-2128, 2000.

18. Rekasi Z, Czompoly T, Schally AV and Halmos G: Isolation and sequencing of cDNAs for splice variants of growth hormonereleasing hormone receptors from human cancers. Proc Natl Acad Sci USA 97: 10561-10566, 2000.

19. Havt A, Schally AV, Halmos G, Varga JL, Toller GL, Horvath JE, Szepeshazi K, Koster F, Kovitz K, Groot K, Zarandi $\mathrm{M}$ and Kanashiro $\mathrm{CA}$ : The expression of the pituitary growth hormone-releasing hormone receptor and its splice variants in normal and neoplastic human tissues. Proc Natl Acad Sci USA 102: 17424-17429, 2005.

20. Müller EE, Locatelli V and Cocchi D: Neuroendocrine control of growth hormone secretion. Physiol Rev 79: 511-607, 1999.

21. Ramirez JL, Catano JP, Torronteras R, Martinez-Fuentes AJ, Frawley LS, Garcia-Navarro S and Garcia-Navarro F: Growth hormone $(\mathrm{GH})$-releasing factor differentially activates cyclic adenosine $3^{\prime}, 5^{\prime}$-monophosphate- and inositol phosphate dependent pathways to stimulate GH release in two pocrine somatotrope subpopulations. Endocrinology 140: 1752-1759, 1999.

22. Siriwardana G, Bradford A, Coy D and Zeitler P: Autocrine/ paracrine regulation of the breast cancer cell proliferation by growth hormone releasing hormone via Ras, Raf and mitogenactivated protein kinase. Mol Endocrinol 20: 2010-2019, 2006.

23. Schally A and Varga JL: Anatgonists of growth hormonereleasing hormone in oncology. Comb Chem High Throughput Screen 9: 163-170, 2006.

24. Chomczynski P and Sacchi N: Single-step method of RNA isolation by acid guanidinium thiocyanate-phenol-chloroform extraction. Anal Biochem 162: 165-159, 1987.

25. Kiaris H, Schally AV, Varga JL, Groot K and Armatis P: Growth hormone-releasing hormone: an autocrine growth factor for small cell lung carcinoma. Proc Natl Acad Sci USA 96: 14894-14898, 1999. 
26. Busto R, Schally AV, Braczkowski R, Plonowski A, Krupa M, Groot K, Armatis P and Varga JL: Expression of mRNA for growth hormone-releasing hormone and splice variants of GHRH receptors in human malignant bone tumors. Regul Pept 108: 47-53, 2002.

27. Plonowski A, Schally AV, Busto R, Krupa M, Varga JL and Halmos G: Expression of growth hormone-releasing hormone $(\mathrm{GHRH})$ and splice variants of GHRH receptors in human experimental prostate cancers. Peptides 23: 1127-1133, 2002.

28. Csernus V, Schally AV and Groot K: Effect of GHRH and peptides from the vasoactive intestinal peptide family on cAMP production of human cancer cell lines in vitro. J Endocrinol 163: 269-280, 1999.

29. Pombo CM, Zaldive J, Gaylinn BD and Dieguez C: Growth hormone-releasing hormone stimulates mitogen-activated protein kinase. Endocrinology 141: 2113-2119, 2000.

30. Jungwirth A, Schally AV, Pinski J, Groot K, Armatis P and Halmos G: Growth hormone-releasing hormone antagonist MZ-4-71 inhibits in vivo proliferation of Caki-I renal adenocarcinoma. Proc Natl Acad Sci USA 94: 5810-5813, 1997.

31. Pinski J, Schally AV, Groot K, Halmos G, Szepeshazi K, Zarandi $\mathrm{M}$ and Armatis P: Inhibition of growth of human osteosarcomas by antagonists of growth hormone-releasing hormone. J Natl Cancer Inst 87: 1787-1794, 1995.

32. Csernus VJ, Schally AV, Kiaris H and Armatis P: Inhibition of growth, production of insulin-like growth factor-II (IGF-II), and expression of IGF-II mRNA of human cancer cell lines by antagonistic analogs of growth hormone-releasing hormone in vitro. Proc Natl Acad Sci USA 96: 3098-3103, 1999.
33. Kahan Z, Arencibia JM, Csernus VJ, Groot K, Kineman RD, Robinson WR and Schally AV: Expression of growth hormonereleasing hormone (GHRH) messenger ribonucleic acid and the presence of biologically active GHRH in human breast, endometrial, and ovarian cancers. J Clin Endocrinol Metab 84: 582-589, 1999.

34. Chatzistamou I, Schally AV, Varga JL, Groot K, Busto R, Armatis P and Halmos G: Inhibition of growth and metastases of MDA-MB-435 human estrogen-independent breast cancers by an antagonist of growth hormone-releasing hormone. Anticancer Drugs 12: 761-768, 2001.

35. Rekasi Z, Varga JL, Schally AV, Plonowski A, Halmos G, Csernus B, Armatis P and Groot K: Antiproliferative actions of growth hormone-releasing hormone antagonists on MiaPaCa-2 human pancreatic cancer cells involve cAMP independent pathways. Peptides 22: 879-886, 2001

36. Barabutis N, Tsellou E, Schally AV, Kouloheri S, Kalofoutis A and Kiaris H: Stimulation of proliferation of MCF-7 breast cancer cells by a transfected slpice variant of growth hormonereleasing hormone receptor. Proc Natl Acad Sci USA 27: 5575-5579, 2007.

37. Kiaris H, Chatzistamou I, Schally A, Halmos G, Varga J, Koutdelimi and Kalofoutis A: Ligand-dependent and independent efects of splice variant 1 of growth hormone-releasing hormone receptor. Proc Natl Acad Sci USA 100: 9512-9517, 1999.

38. Barabutis N and Schally AV: Knocking down gene expression for growth hormone-releasing hormone inhibits proliferation of human cancer cell lines. Br J Cancer (In press). 